\title{
Utilization of the Library and Internet as a Source of Scientific Information by the Nursing Students
}

\author{
Supriya Chinchpure*, Aiswarya TR, Anisha Raju, Anjumol KR, Archana S, Aswathy AR and Artee T Barate \\ Department of Obstetrics \& Gynecology Nursing, Sadhu Vaswani College of nursing, India
}

Received: December 12, 2017; Published: February 23, 2018

*Corresponding author: Supriya Chinchpure, Department of Obstetrics \& Gynecology Nursing, Sadhu Vaswani College of nursing, 10-10/1 Koregaon Park Pune, India, Email: supriyachinchpure@gmail.com

\begin{abstract}
Background: In the past few decades library was the only source of information. Most of people were totally dependent library for gaining knowledge. After the 20th century there has been marked increase in internet usage. Some people consider libraries to be unnecessary due to the availability of information on the Internet. Others, however, believe that libraries can still play an important role in education. A library is much more than a means of distribution of the information; it also has a vital role in academic purpose. Library developed a wide range services to meet the educational objectives of their parent institutions. School libraries clearly need to support the curriculum, but they also collect books and other materials to encourage reading and spirit of enquiring, as well as to meet the need of the teacher and students. On the one hand, the Internet enables the users to obtain a wide range of information regardless of their locations.

Students would not travel to a library in order to read books or any other reading materials as they have access to the information via the web research. For example, if an individual inserts few keywords on the websites, he will be given a rich variety of the related information from all over the world within a minute. Therefore, using the Internet for acquiring information may cause a situation where visiting libraries seem to have no necessity for the Internet users. Libraries have been given less importance in society, compared to the past. While some people believe that the libraries are no longer essential because of the Internet, Upcoming digitalized world is totally dependent on internet. Various researches have been done in different profession on comparing use of internet and library as scientific source of information, thus investigators finds interest to assess the scientific sources of information in nursing profession.
\end{abstract}

\section{Objectives of the Study}

a) To determine the utilization of library books as a source of scientific information by students

b) To assess the utilization of internet as a source of scientific information by nursing student.

c) To assess the satisfaction of library \& internet utilization by nursing students.

\section{Research Methodology}

a) Research Approach: Descriptive Survey

b) Research Design: Non Experimental Descriptive cross sectional

c) Setting: Selected nursing college

d) Population: Nursing Feminist

e) Sample: Nursing students of Selected nursing college

f) Sampling technique: Non probability convenient sampling

g) Sample Size: 105 nursing students

h) Data collection tool: Self structured questionnaire.

The tool consists of 4 sections:

i. Section A: Demographic data

ii. Section B: Utilization of library

iii. $\quad$ Section C: Utilization of internet 
Results:

Finding of Demographic data: It includes code no., age, course, year, source of information. Majority finding revealed that (91.74\%) nursing students are using both internet and library as source scientific information for the academic purpose.

Findings on Utilization of library

A. Major Finding Revealed are as Follows:

a) On analysis of data related to helpfulness of library in academic purpose revels that majority of students i.e. $83.80 \%$ found library to be helpful and $16.19 \%$ felt it is somewhat helpful for their academic purpose.

b) On examination of purpose of visit to library result shows that students mostly prefer text books i.e. $32.94 \%$ for studies, while $22.48 \%$ for study purpose, while $15.11 \%$ for reading news paper, while $13.95 \%$ for reference materials. While $11.62 \%$ use to refer journals. And $3.87 \%$ use library for other than academic purposes.

c) On analysis of data related to frequency of library use shows that majority of students ie $46.89 \%$ of use library when there is necessary and $31.03 \%$ students visit library daily .

d) On analysis of data related to duration of each visit revels that majority (57.14\%) of students using library more than 30 minutes while $42.85 \%$ students using library less than 30 minutes.

e) On examination of locating the desired material in library most of students ie $41.17 \%$ seeking help from librarian for locating desired materials , while $35.29 \%$ searching through shelves, $12.29 \%$ searching through catalogue and $11.11 \%$ locating desired materials by seeking help from colleagues.

f) On examination of selection criteria reveals that $56.33 \%$ of students are selecting book for their study as per the author, while $24.64 \%$ are selecting as per the teacher/mentor.and $19.01 \%$ use publication as their selection criteria.

g) On analysis of data related to important resources for academic purpose reveals that majority ie $47.22 \%$ of students use text book as an important resource for their academic purpose, while $28.33 \%$ use reference material, while $8.33 \%$ use journals, while $6.66 \%$ use dessertations,while $5.55 \%$ use supplementary readings and $3.88 \%$ use magazines.

h) On analysis of data related to locating desired information reveals that majority ie, $47.22 \%$ of student find easy to locate desired information, while $37.96 \%$ find it is somewhat easy,while $12.03 \%$ find it is very easy and $2.77 \%$ said that locating desired information is not at all easy.

i) On analysis of data related to adequacy of desired information from library reveals that maximum students ie $82.85 \%$ said that library is providing adequate information and $17.14 \%$ student said that it is not providing adequate information.

j) On examamination of advantages of reading material in library reveals that majority ie $27.18 \%$ of students using library because they get materials which students can't afford to buy. While $20.27 \%$ feels library provides major source of scientific information. While $17.97 \%$ feels that library provides relevant and realistic information, while $15.20 \%$ feels library provides authentic reference, while $10.13 \%$ fells that the information from library books are current and updated and $9.21 \%$ use for reading supplementary materials.

k) On analysis of data related to asking help from librarian during library visit reveals that majority ie $54.28 \%$ of students seek help from librarian in some visit, while $25.71 \%$ rarely ask help from librarian .and $20 \%$ students ask help every visit.

\section{Findings on Utilization of Internet:}

A. Major Finding Revealed are as Follows

a) On analysis of data related to helpfulness of internet in academic reveals that majority $81.90 \%$ of students said that internet is helpful in their academic purpose, while $16.19 \%$ said that it is somewhat helpful for their academic purposes and $1.90 \%$ said it is not helpful for their academic purposes.

b) On examination of purpose of accessing internet reveals that majority of students i.e. $24.50 \%$ access internet for reference materials, while $21.07 \%$ use internet for other than academic purposes, while $17.15 \%$ use internet to study for examination, $16.66 \%$ students use internet to refer text book , 10.29\% for reading news paper, and $10.29 \%$ use to refer journals.

c) On analysis of data related to frequency of accessing internet reveals that majority of students ie $71.42 \%$ use internet when there is necessary while $14.28 \%$ use internet every day and $14.28 \%$ use internet $2-3$ times a week.

d) On analysis of data related to duration of each visit reveals that majority of students i.e. $65.71 \%$ are using internet more than 30 minutes in each visit and 34.28\%is using less than 30 minutes in each visit .

e) On examination of possess of locating desired material found that majority of students are locating the desired material through search engine i.e. $58.77 \%$ while $21.37 \%$ search through online catalogs, while $13.74 \%$ asking help from colleagues and only $6.10 \%$ is seeking guidance from librarian .

f) On examination of selection criteria for desired materials from internet reveals that $34.61 \%$ of students are selecting information for their study as per the author while $33.84 \%$ students are using publication as their selection criteria and $31.53 \%$ are selecting as per the teacher/mentor. 
g) On analysis of data related to important resources for academic purpose reveals that majority ie $33.51 \%$ students are use e-reference, while $20.21 \%$ use e- text books for study , while $20.21 \%$ use supplementary readings, $11.70 \% \%$ use dissertations, $7.97 \%$ use e-journals and $6.38 \%$ e- magazines.

h) On analysis of data related to locating desired information from internet reveals that majority ie $42.85 \%$ students are found easy to locate desired information, while $37.14 \%$ find that it is very easy and $20 \%$ of them felt it is somewhat easy.

i) On analysis of data related to adequacy of desired information revel that maximum student i.e. $89.50 \%$ said that internet provides adequate information for their academic purpose and $10.47 \%$ felt information is inadequate.

j) On examamination of advantages of reading material available in internet reveals majority i.e. $25.87 \%$ of students felt that reading materials available in internet are current and updated. while $17.54 \%$ feels it is relevant and realistic information ,while $16.66 \%$ feels that the advantage of using internet is they get material that students cannot afford to buy, $13.59 \%$ students found that internet is providing major source of scientific information. And other $13.59 \%$ feels that internet provides authentic reference material and $12.71 \%$ said that internet gives supplementary materials.

k) On analysis of data related to asking help from librarian during visit reveals that majority i.e. $39 \%$ of student asks help from librarian rarely. While $31.42 \%$ ask help in some visit, while $5.71 \%$ ask help in every visit and $23.80 \%$ never ask help from librarian for accessing internet for their study purpose.

\section{Finding on comparison of satisfaction on utilization of college library and internet}

A. Major Finding Revealed are as Follows: Maximum students are satisfied with college library over internet i.e. $40 \%$ students are very satisfied with utilization of college library, $56.19 \%$ is satisfied and $3.80 \%$ is less satisfied with the utilization of college library. Whereas $26.66 \%$ students are very satisfied with the utilization of collage internet, $60 \%$ is satisfied and $13.33 \%$ is less satisfied with the utilization of college internet.

Conclusion: Majority of students using library as a major source of scientific information for their academic purposes over internet i.e. $1.90 \%$ students are having good utilization of library for their academic purpose and $57.14 \%$ having average utilization of library and $42.95 \%$ had poor utilization of library. Whereas $0.95 \%$ students are using internet as source of information, $44.76 \%$ are having average use of internet for the academic purposes and $54.28 \%$ is poor in utilization of internet for their studies.

Keywords: Utilization; Source; Library \& Internet

\section{Introduction}

Information is a vital and indispensable component of any academic environment. It makes for effectiveness in any academic system. Both faculty and students need to use information daily in their various academic endeavors. For decades, faculty and students have actively use library and its resources as their main information sources. Library increase the knowledge without any boundary and also inspires the students to develop a habit of reading books. There for it provides real satisfaction and pleasures to student as well as facultiesm [1] we now live in the information age where access too many internet resource is just a few clicks away. The term internet has been coined from a concept inter-networking that denotes interaction between networks of computers. It is an umbrella under which different network, small and big, freely exchange information across the globe. It provides to assess to the most diversified source of information hosted by individual and various organization worldwide on a vast network on serves [1].

Nowadays, the internet in the education sector plays an important role, especially in the process of empowering the technology in to the educational activities. In other side it can be the most effective way to increase the students' knowledge. Internet has become a part of library environment today it has added a great value to the library and information service [2]. The internet is not a substitute for the library, but a search tool to be used in addition to traditional sources in the library. No one would deny that with the high accessibility of the internet, libraries have been given less importance in society, compared to the past. While some people believe that the public libraries are no longer essential because of the internet, libraries still make a positive contribution in our societies [1].

On the one hand, the internet enables the users to obtain a wide range of information regardless of their locations. People would not travel to a local library in order to read books or any other reading materials as they have access to the information via the web research [2]. Therefore, using the internet for acquiring information may cause a situation where visiting libraries seem to have no necessity for the internet users. The internet has introduced improvements in technology, communication and online entertainment but it is also incredibly useful for education purposes as well. Teachers use internets to supplement the lesion and a number of prestigious universities have open up free online lectures and courses to everyone. It has even allowed retired teachers to read to and educate children in poorer countries. Widespread use of the internet has opened up a substantial amount of knowledge to a much broader range of people than ever before. The internet contains a wealth of knowledge that is available instantly upon any search. Because of this, the internet has superseded libraries as a source for information gathering and research. Many teachers will now ask students to visit specific website to study from home, and online encyclopedias provide masses of knowledge of every topic imaginable. The variety of sources allows students to pursue subject in much greater details rather than being limited to whatever teacher's sends home.2 Libraries have been given less importance 
in society, compared to the past. While some people believe that the libraries are no longer essential because of the Internet, Upcoming digitalized world is totally dependent on internet.

Problem Statement: "A study to assess utilization of the library and internet as a source of scientific information by the nursing students in selected nursing students in selected nursing college"

Objectives of the Study: To determine the utilization of library books as a source of scientific information by students

a) To assess the utilization of internet as a source of scientific information by nursing student.

b) To assess the satisfaction of library \& internet utilization by nursing students.

\section{Materials and Methods}

a) Research Approach: Descriptive Survey.

b) Research Design: Non Experimental Descriptive crosses sectional.

c) Setting: Selected nursing college.

d) Population: Nursing Feminist.

e) Sample: Nursing students of selected nursing college.

f) Sampling technique: Non probability convenient sampling.

g) Sample Size: 105 nursing students.

h) Inclusion Criteria: The nursing students (BSc, MSc, PBBSc) who are willing to participate in this study.

i) Exclusion Criteria: First year BSc nursing student.

j) Data collection tool: Self structured questionnaire.

The tool consists of 4 sections

i. Section A: Demographic data

ii. Section B: Utilization of library

iii. Section C: Utilization of internet

iv. Section D: Satisfaction scale on library and internet

\section{Description of the Tool}

The tool was used in this study is self -structured questionnaire, which comprises of 4 parts

a. Section A: It includes demographic data like Age, Course, Year, and Source of information for academic purposes.

b. Section B: (utilization of library) - It consist of 12 questions which to assess utilization of library by nursing students as a source of scientific information. Good $=27-39$, Average $=14-26$, Poor $=1-13$.

c. Section C: (utilization of internet)- It consist of 12 questions which to assess utilization of internet by nursing students as a source of scientific information. Good $=27-39$, Average $=14-26$, Poor $=1-13$.

d. Section D: 1 (satisfaction on utilization of college library) - It consist of 15 items. The total scoring of satisfaction scale is 1- 60. Each item having scoring scale from 1-4, 1=Not satisfied, 2=Less satisfied, 3=Satisfied, 4=Very satisfied.

\section{Validity}

Tool was validated by nursing experts, librarian and statistician.

\section{Reliability}

Test -re-test method of reliability was used for Self structured questionnaire and score of 0.988 was achieved, whereas for satisfaction scale split half method was used and a score of 0.99 was achieved. both the values suggest that the tool is highly reliable.

\section{Procedure for Data Collection}

A formal permission was obtained from the concerned authority's data and date will be pre decided the investigator introduced self and inform the samples about the nature of study so as to ensure better cooperation during the data collection. Subject was assured about the confidentiality of the data.

\section{Plan for Data Analysis}

The data analysis was planned to include frequency distribution for demographic data and all section will be plotted in terms of bar graph to understand the utilization of library and internet.

\section{Results}

\section{Organization of Data}

The collected data is tabulated, organized and analyze under the following heading

a) Section A: It deals with the analysis of the basic source of information of the sample.

b) Section B: It deals with the analysis of the data related to utilization of the library of the sample.

c) Section C: It deals with the analysis of the data related to utilization of the internet of the sample.

d) Section D: It deals with the analysis of the satisfaction scale for library and internet of the sample.

\section{Section A}

Table 1: Analysis of data related to basic source of information among nursing students for their academic purpose.

\begin{tabular}{|c|c|c|}
\hline Source of Information & Score & Percentage \\
\hline Only library & 5 & $4.58 \%$ \\
\hline Only internet & 0 & $0 \%$ \\
\hline Both & 100 & $91.74 \%$ \\
\hline Other & 4 & $3.66 \%$ \\
\hline
\end{tabular}

The above (Table 1) and (Figure 1) shows that maximum i.e., 91.74\% of nursing (BSc, PBBSc, MSc) students are using both internet 
and library as source of information for academic purpose.4.58\% students only using library as a source of information for academic purpose. There are no students using only internet $(0 \%)$ as a source of information for academic purpose.

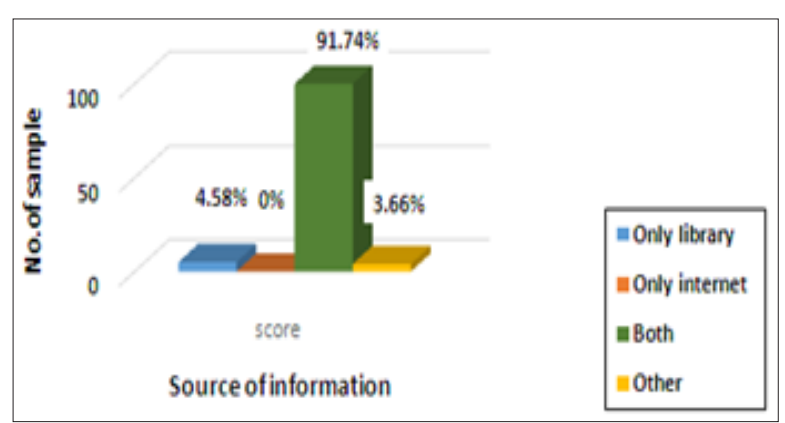

Figure 1: Source of information for academic purpose.

\section{Section B}

The above (Table 2) and (Figure 2) shows that helpfulness of library in academic purpose. $83.80 \%$ of students say that library is helpful in their academic purpose and $16.19 \%$ said that it is somewhat helpful for their academic purposes. The above (Table 3) and (Figure 3 ) shows that $32.94 \%$ students use library to refer text book, $22.48 \%$ for study purpose, $15.11 \%$ for reading news paper, and $13.95 \%$ for reference materials. $11.62 \%$ use to refer journals. And $3.87 \%$ use library for other than academic purposes. The above (Table 4) and (Figure 4) shows the frequency of library usage, $46.89 \%$ students said that they use library when there is necessary and $31.03 \%$ students visit library daily. The above (Table 5) and (Figure 5) shows that duration of library use in each visit. $57.14 \%$ students are using library more than 3 o minutes. Whereas $42.85 \%$ students using library less than 30 minutes. The above (Table 6) and (Figure 6) shows that $41.17 \%$ locating desired materials by, seeking help from librarian. 35.29\% searching through shelves, $12.29 \%$ searching through catalogue and $11.11 \%$ locating desired materials by seeking help from colleagues.

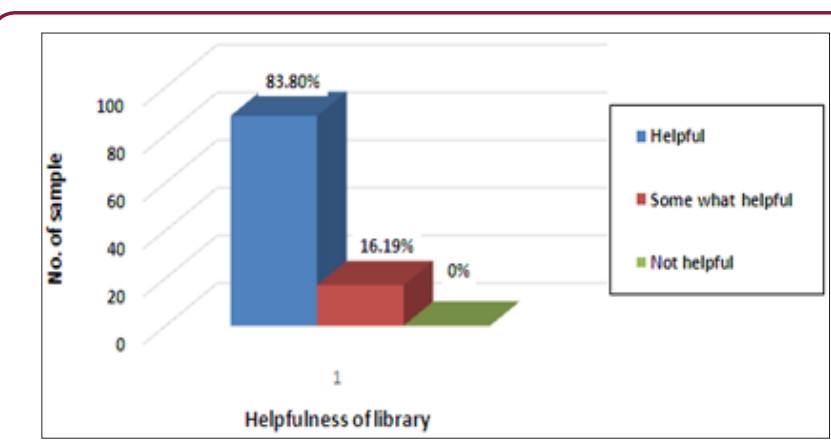

Figure 2: Helpfulness of library in academic purpose.

Table 2: Analysis of data related to helpfulness of library in academic purpose.

\begin{tabular}{|c|c|c|}
\hline Helpfulness of Library & Score & Percentage \\
\hline Helpful & 88 & $83.80 \%$ \\
\hline Somewhat helpful & 17 & $16.19 \%$ \\
\hline Not helpful & 0 & 0 \\
\hline
\end{tabular}

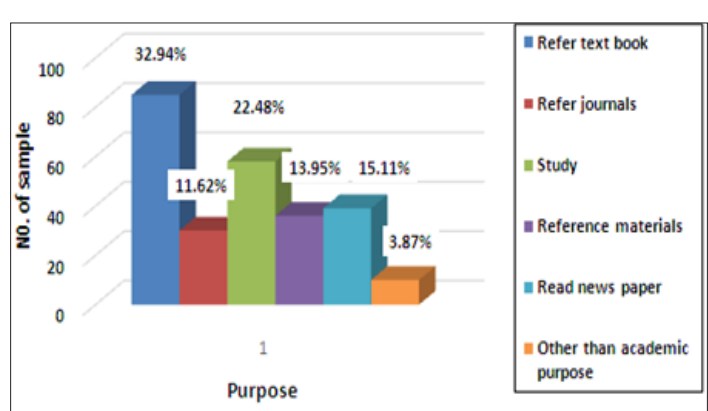

Figure 3: Purpose of visiting Library.

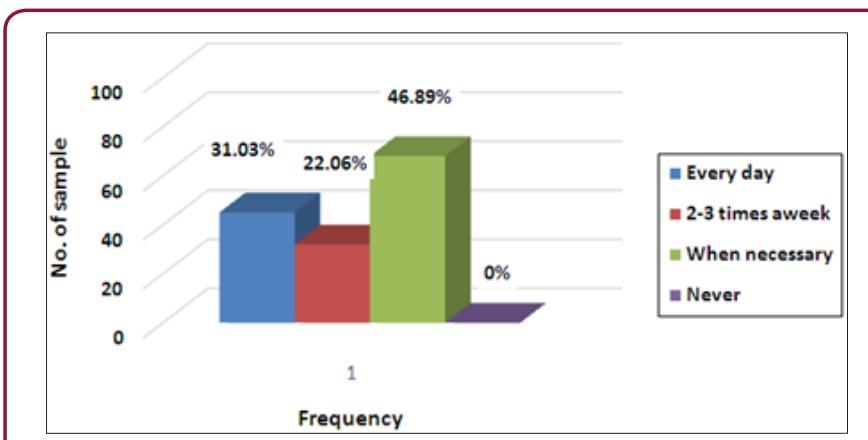

Figure 4: Frequency of library use.

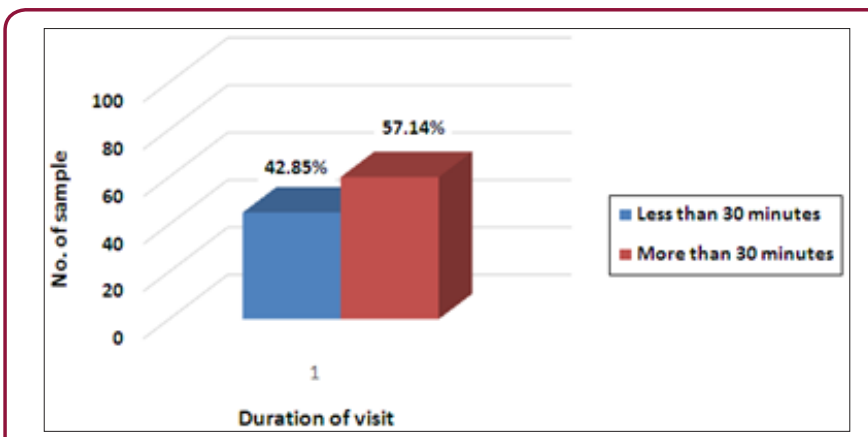

Figure 5: Duration of visit.

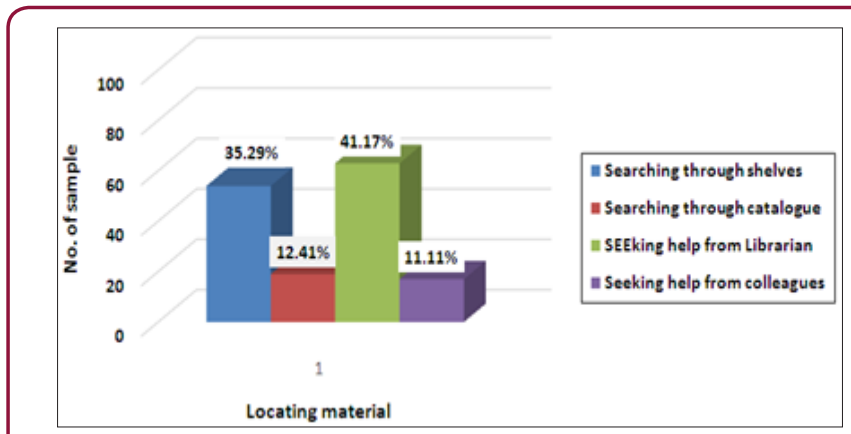

Figure 6: Locating desired materials.

Table 3: Analysis data related to purpose of visiting library.

\begin{tabular}{|c|c|c|}
\hline Purposes & Score & Percentage \\
\hline Refer text book & 85 & $32.94 \%$ \\
\hline Refer journals & 30 & $11.62 \%$ \\
\hline Study & 58 & $22.48 \%$ \\
\hline Reference materials & 36 & $13.95 \%$ \\
\hline
\end{tabular}




\begin{tabular}{|c|c|c|}
\hline Read news paper & 39 & $15.11 \%$ \\
\hline Other than academic purpose & 10 & $3.87 \%$ \\
\hline
\end{tabular}

Table 4: Analysis of data related to frequency of library use.

\begin{tabular}{|c|c|c|}
\hline Frequency & Score & Percentage \\
\hline Every day & 45 & $31.03 \%$ \\
\hline 2-3 times a week & 32 & $22.06 \%$ \\
\hline When necessary & 68 & $46.89 \%$ \\
\hline Never & 0 & 0 \\
\hline
\end{tabular}

Table 5: Analysis of data related to duration of each visit.

\begin{tabular}{|c|c|c|}
\hline Duration & Score & Percentage \\
\hline Less than 30 minutes & 45 & $42.85 \%$ \\
\hline More than 30 minutes & 60 & $57.14 \%$ \\
\hline
\end{tabular}

Table 6: Analysis of data related to locating the desired material in library.

\begin{tabular}{|c|c|c|}
\hline Locating Material & Score & Percentage \\
\hline Searching through shelves & 54 & $35.29 \%$ \\
\hline Searching through catalogue & 19 & $12.41 \%$ \\
\hline Seeking help from Librarian & 63 & $41.17 \%$ \\
\hline Seeking help from colleagues & 17 & $11.11 \%$ \\
\hline
\end{tabular}

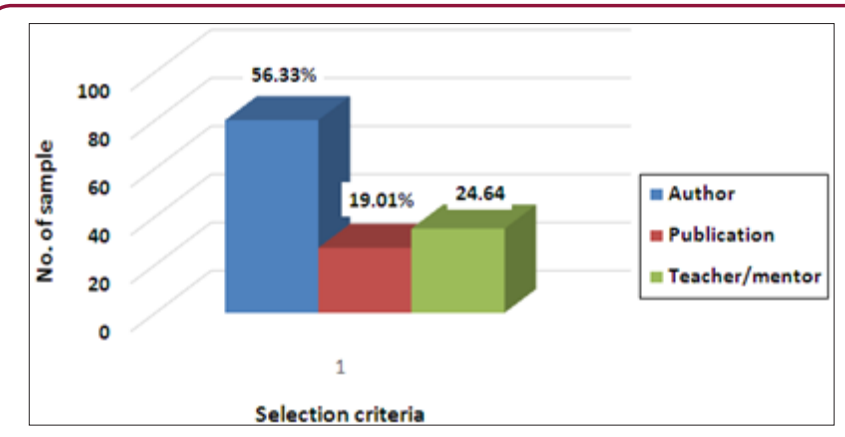

Figure 7: Selection Criteria.

The above (Table 7) and (Figure 7) shows that $56.33 \%$ of students are selecting book for their study as per the author, $24.64 \%$ are selecting as per the teacher/mentor. And 19.01\% use publication as their selection criteria. The above (Table 8) and (Figure 8) shows that $47.22 \%$ students use text book as an important resource for their academic purpose $28.33 \%$ use reference material ,8.33\% use journals,6.66\% use dissertations, $5.55 \%$ use supplementary readings and $3.88 \%$ use magazines. The above (Table 9) and (Figure 9) shows that $42.22 \%$ find easy to locate desired information, $37.96 \%$ find it is somewhat easy, $12.03 \%$ find it is very easy and $2.77 \%$ said that locating desired information is not at all easy. The above (Table 10) and (Figure 10) shows that maximum students i.e. $82.85 \%$ said that library is providing adequate information and $17.14 \%$ said that it is not adequate. The above (Table 11) and (Figure 11) shows that $27.18 \%$ of student using library material that they can't afford to buy.20.27\% said it is major source of scientific information.17.97\% said that library provides relevant and realistic information, $15.20 \%$ said library provides authentic reference, $10.13 \%$ said the information from library books are current and updated and 9.21\% use for reading supplementary materials.

Table 7: Analysis of data related to selection criteria.

\begin{tabular}{|c|c|c|}
\hline Selection & Score & Percentage \\
\hline Author & 80 & $56.33 \%$ \\
\hline Publication & 27 & $19.01 \%$ \\
\hline Teacher/mentor & 35 & $24.64 \%$ \\
\hline
\end{tabular}

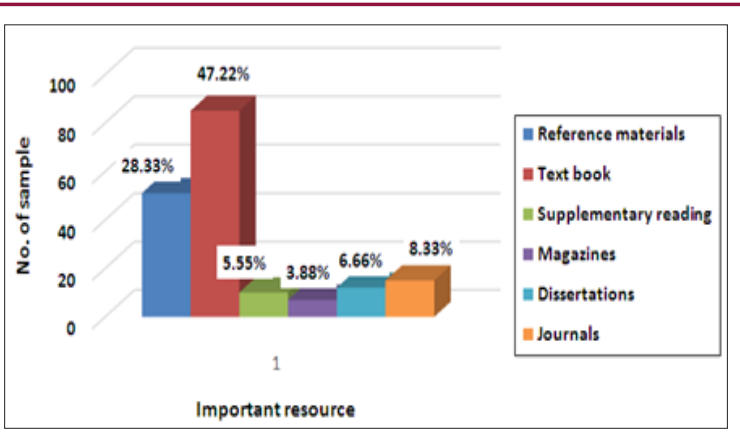

Figure 8: Important resources for academic purposes.

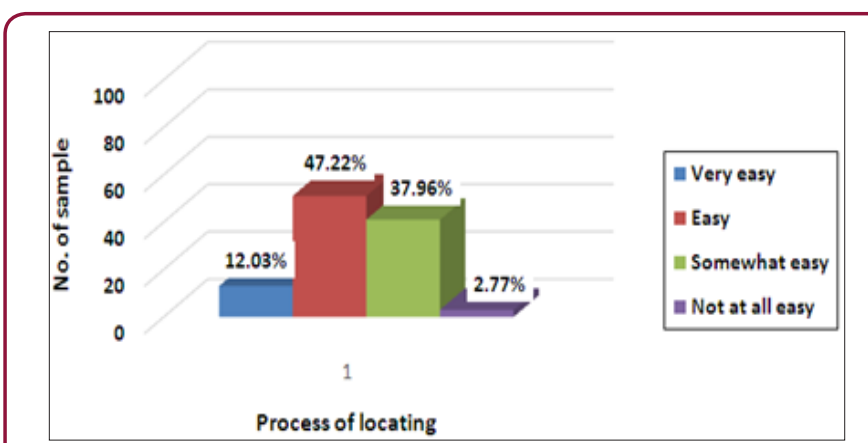

Figure 9: Process of locating desired information.

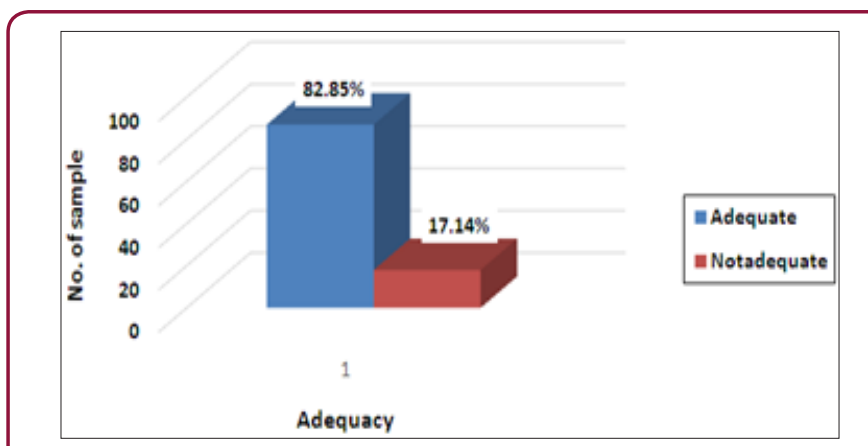

Figure 10: Adequacy of desired information.

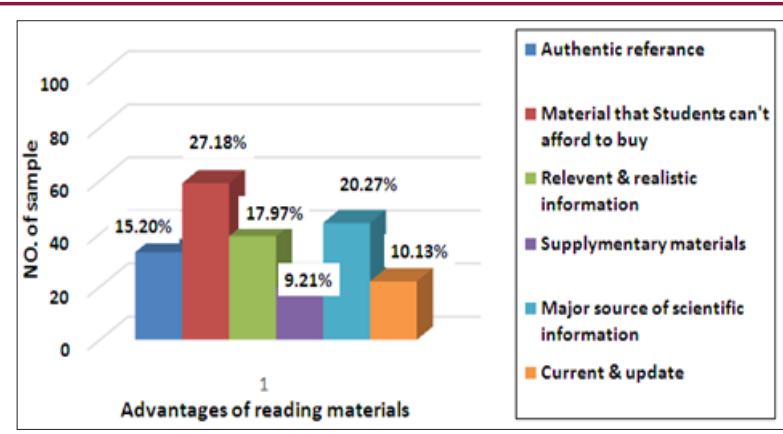

Figure 11: Advantages of reading materials in library. 
Table 8: Analysis of data related to important resources for academic purposes.

\begin{tabular}{|c|c|c|}
\hline Resources & Score & Percentage \\
\hline Reference materials & 51 & $28.33 \%$ \\
\hline Text book & 85 & $47.22 \%$ \\
\hline Supplementary reading & 10 & $5.55 \%$ \\
\hline Magazines & 7 & $3.88 \%$ \\
\hline Dissertations & 12 & $6.66 \%$ \\
\hline Journals & 15 & $8.33 \%$ \\
\hline
\end{tabular}

Table 9: Analysis of data related to process of locating desired information.

\begin{tabular}{|c|c|c|}
\hline Process of Location & Score & Percentage \\
\hline Very easy & 13 & $12.03 \%$ \\
\hline Easy & 51 & $47.22 \%$ \\
\hline Somewhat easy & 41 & $37.96 \%$ \\
\hline Not at all easy & 3 & $2.77 \%$ \\
\hline
\end{tabular}

Table 10: Analysis of data related to adequacy of desired information.

\begin{tabular}{|c|c|c|}
\hline Adequacy & Score & Percentage \\
\hline Adequate & 87 & $82.85 \%$ \\
\hline Not adequate & 18 & $17.14 \%$ \\
\hline
\end{tabular}

Table 11: Analysis of data related to advantages of reading material in library.

\begin{tabular}{|c|c|c|}
\hline Advantages & Score & Percentage \\
\hline Authentic reference & 33 & $15.20 \%$ \\
\hline $\begin{array}{c}\text { Material that Students can't afford } \\
\text { to buy }\end{array}$ & 59 & $27.18 \%$ \\
\hline Relevant \& realistic information & 39 & $17.97 \%$ \\
\hline Supplementary materials & 20 & $9.21 \%$ \\
\hline $\begin{array}{c}\text { Major source of scientific } \\
\text { information }\end{array}$ & 44 & $20.27 \%$ \\
\hline Current \& update & 22 & $10.13 \%$ \\
\hline
\end{tabular}

The above (Table 12) and (Figure 12) shows that $54.28 \%$ students seek help from librarian in some visit, $25.71 \%$ rarely ask help from librarian .and 20\% students ask help every visit the above (Table 13) and (Figure 13) shows that helpfulness of library in academic purpose. $81.90 \%$ students say that internet is helpful in their academic purpose, $16.19 \%$ said that it is somewhat helpful for their academic purposes and $1.90 \%$ said it is not helpful for their academic purposes. The above (Table 14) and (Figure 14) shows that $24.50 \%$ students access internet for reference materials, $21.07 \%$ use internet for other than academic purposes, $17.15 \%$ visit the coputerlad to study for examination, $16.66 \%$ students use internet to refer text book , $10.29 \%$ for reading news paper, and $10.29 \%$ use to refer journals. The above (Table 15) and (Figure 15) shows that $71.42 \%$ of students use internet when there is necessary, $14.28 \%$ use internet every day and $14.28 \%$ use internet2-3 times a week. The above (Table 16) and (Figure 16) shows that $65.71 \%$ students using internet more than 30 minutes in each visit. And $34.28 \%$ is using less than 30 minutes in each visit.

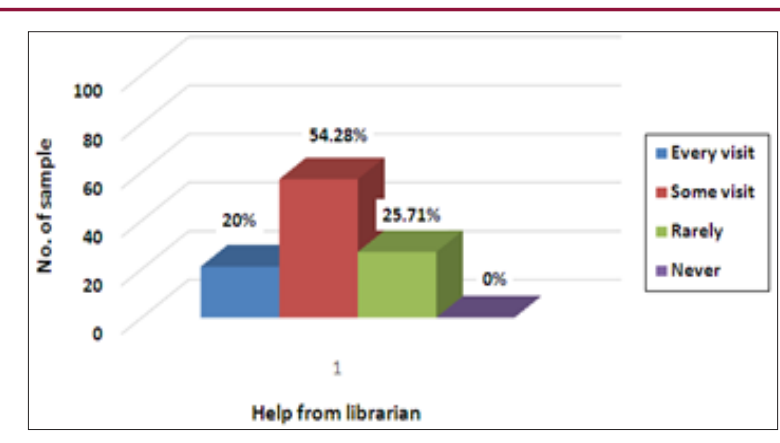

Figure 12: Help from librarian.

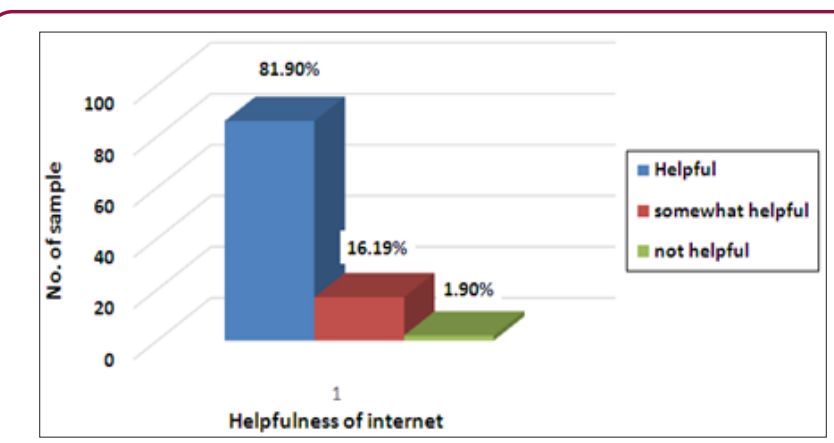

Figure 13: Helpfulness of interest in academic.

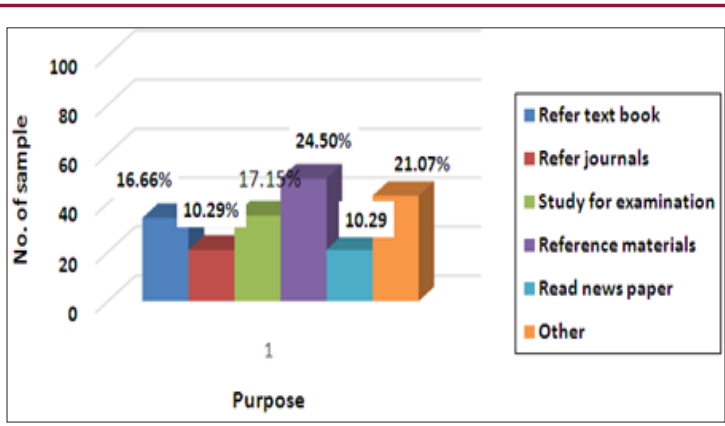

Figure 14: Purpose of accessing internet.

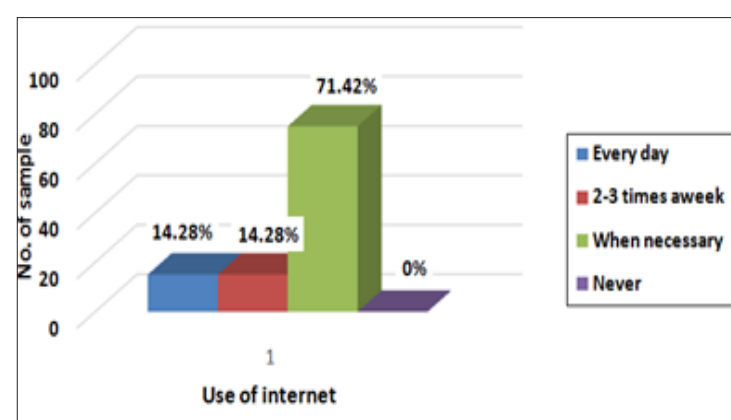

Figure 15: Frequency of accessing internet.

Table 12: Analysis of data related to help from librarian.

\begin{tabular}{|c|c|c|}
\hline Help from Librarian & Score & Percentage \\
\hline Every visit & 21 & $20 \%$ \\
\hline Some visit & 57 & $54.28 \%$ \\
\hline Rarely & 27 & $25.71 \%$ \\
\hline Never & 0 & 0 \\
\hline
\end{tabular}


Table 13: Analysis of data related to helpfulness of internet in academic.

\begin{tabular}{|c|c|c|}
\hline Helpfulness of Internet & Score & Percentage \\
\hline Helpful & 86 & $81.90 \%$ \\
\hline somewhat helpful & 17 & $16.19 \%$ \\
\hline not helpful & 2 & $1.90 \%$ \\
\hline
\end{tabular}

Table 14: Analysis of data related to purpose of assessing internet.

\begin{tabular}{|c|c|c|}
\hline Purposes & Score & Percentage \\
\hline Refer text book & 34 & $16.66 \%$ \\
\hline Refer journals & 21 & $10.29 \%$ \\
\hline Study for examination & 35 & $17.15 \%$ \\
\hline Reference materials & 50 & $24.50 \%$ \\
\hline Read news paper & 21 & $10.29 \%$ \\
\hline Other & 43 & $21.07 \%$ \\
\hline
\end{tabular}

Table 15: Analysis of data related to frequency of accesing internet.

\begin{tabular}{|c|c|c|}
\hline Frequency & Score & Percentage \\
\hline Every day & 15 & $14.28 \%$ \\
\hline 2-3 times a week & 15 & $14.28 \%$ \\
\hline When necessary & 75 & $71.42 \%$ \\
\hline Never & 0 & 0 \\
\hline
\end{tabular}

Table 16: Analysis of data related to duration of each visit.

\begin{tabular}{|c|c|c|}
\hline Duration & Score & Percentage \\
\hline Less than 30 minutes & 36 & $34.28 \%$ \\
\hline More than 30 minutes & 69 & $65.71 \%$ \\
\hline
\end{tabular}

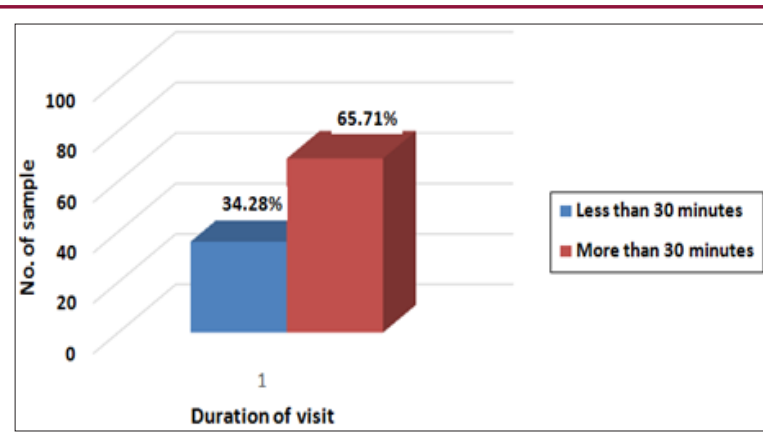

Figure 16: Duration of visit.

The above (Table 17) and (Figure 17) shows that students are locating the desired material through search engine,21.37\% search through online catalogs, $13.74 \%$ asking help from colleagues and only $6.10 \%$ is seeking guidance from librarian. The above (Table 18) and (Figure 18) shows that $34.61 \%$ of students are selecting information for their study as per the author, $33.84 \%$ use publication as their selection criteria. And $31.53 \%$ are selecting as per the teacher/mentor. The above (Table 19) and (Figure 19) shows that $33.51 \%$ students use references as an important resource for their academic purpose, $20.21 \%$ use e- text book, $20.21 \%$ use supplementary readings, $11.70 \% \%$ use dissertations,
7.97\% use E-journals and $6.38 \%$ magazines. The above (Table 20) and (Figure 20) shows that $42.85 \%$ students said that the process of locating desired information in internet is easy and $37.14 \%$ said that it is very easy and $20 \%$ them told it is somewhat easy. The above (Table 21) and (Figure 21) shows $89.50 \%$ students feel that information from internet is adequate for their academic purpose and $10.47 \%$ fell it is in adequate.

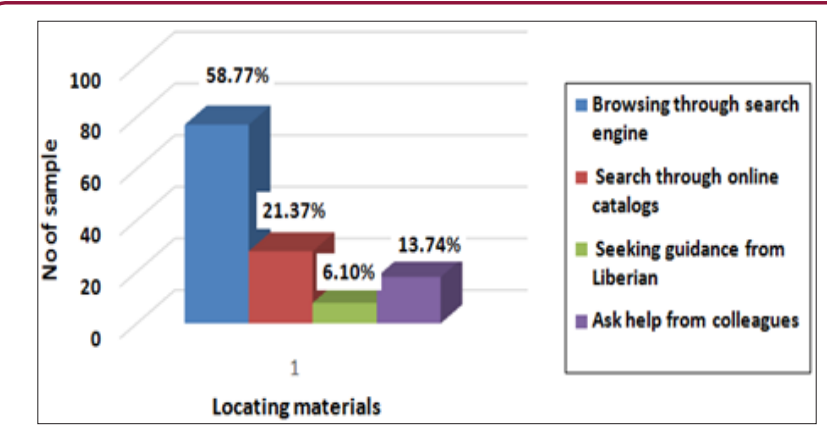

Figure 17: Locating desired material in internet.

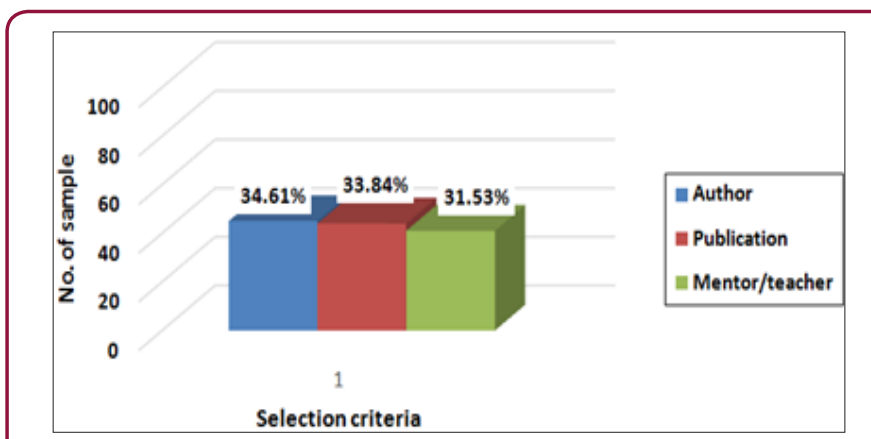

Figure 18: Selection criteria for desired information.

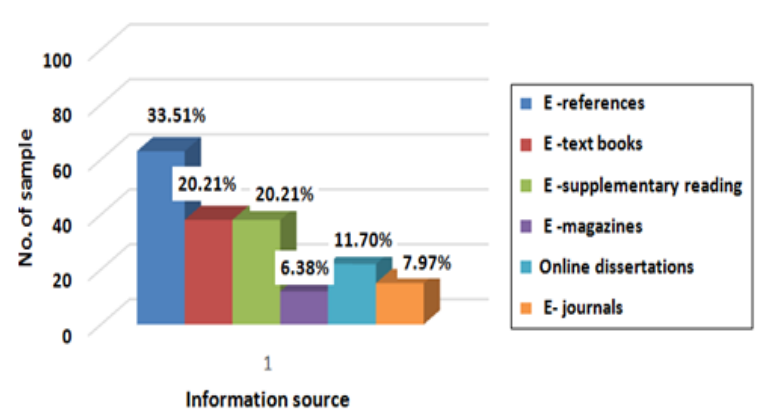

Figure 19: Important information source for academic.

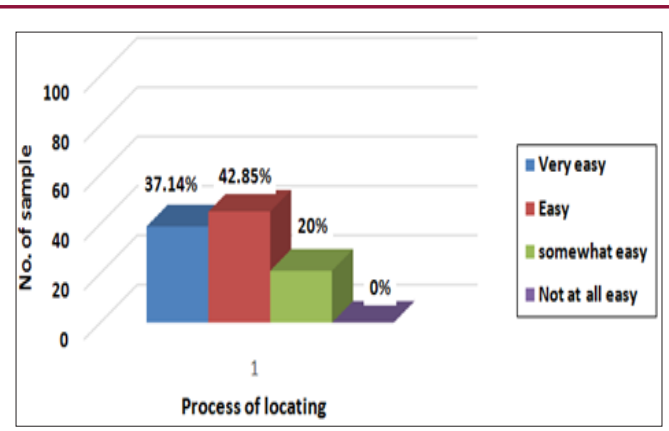

Figure 20: Process of locating desird information. 


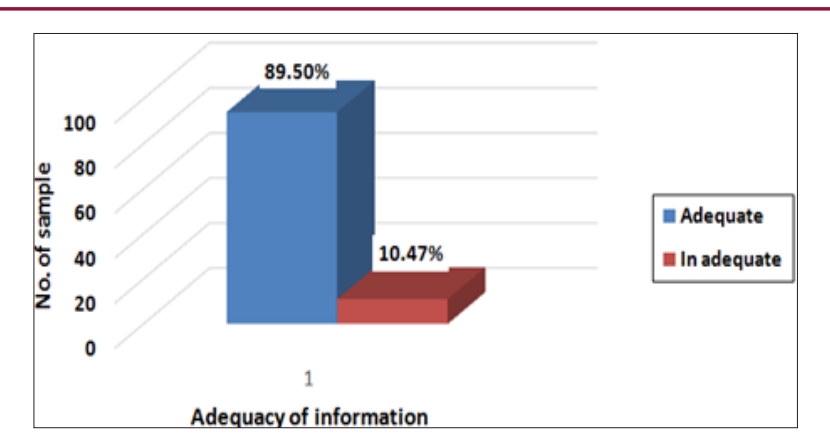

Figure 21: Adequacy of desird information.

Table 17: Analysis of data related to process of locating desired material in internet.

\begin{tabular}{|c|c|c|}
\hline Process of Location & Score & Percentage \\
\hline Browsing through search engine & 77 & $58.77 \%$ \\
\hline Search through online catalogs & 28 & $21.37 \%$ \\
\hline Seeking guidance from Liberian & 8 & $6.10 \%$ \\
\hline Ask help from colleagues & 18 & $13.74 \%$ \\
\hline
\end{tabular}

Table 18: Analysis of data related to selection criteria for desired information.

\begin{tabular}{|c|c|c|}
\hline Criteria & Score & Percentage \\
\hline Author & 45 & $34.61 \%$ \\
\hline Publication & 44 & $33.84 \%$ \\
\hline Mentor/teacher & 41 & $31.53 \%$ \\
\hline
\end{tabular}

Table 19: Analysis of data related to important information source for academic.

\begin{tabular}{|c|c|c|}
\hline Sources & Score & Percentage \\
\hline E -references & 63 & $33.51 \%$ \\
\hline E -text books & 38 & $20.21 \%$ \\
\hline E -supplementary reading & 38 & $20.21 \%$ \\
\hline E -magazines & 12 & $6.38 \%$ \\
\hline Online dissertations & 22 & $11.70 \%$ \\
\hline E- journals & 15 & $7.97 \%$ \\
\hline
\end{tabular}

Table 20: Analysis of data related to process of locating desired information.

\begin{tabular}{|c|c|c|}
\hline Location & Score & Percentage \\
\hline Very easy & 39 & $37.14 \%$ \\
\hline Easy & 45 & $42.85 \%$ \\
\hline somewhat easy & 21 & $20 \%$ \\
\hline Not at all easy & 0 & 0 \\
\hline
\end{tabular}

Table 21: Analysis of data related to adequacy of desired information.

\begin{tabular}{|c|c|c|}
\hline Adequacy & Score & Percentage \\
\hline Adequate & 94 & $89.50 \%$ \\
\hline In adequate & 11 & $10.47 \%$ \\
\hline
\end{tabular}

The above (Table 22) and (Figure 22) shows $25.87 \%$ students said that advantages of reading materials available in internet resources are current and updated,17.54\% feels it is relevent and realistic information, $16.66 \%$ feels that the advantage of using internet is they get material that students cannot aford to buy, $13.59 \%$ students found that internet is providing major source of scientific information.and other $13.59 \%$ feels that internet provides authentic reference material and $12.71 \%$ said that internet gives supplimentery materials. The above (Table 23) and (Figure 23) shows $39 \%$ of student ask help from librarian rarely, $31.42 \%$ ask some visit, $5.71 \%$ ask help in every visit and $23.80 \%$ never ask help from librarian for accessing internet for their study purpose. The above (Table 24) and (Figure 24) shows the utilization of internet and library; $1.90 \%$ students are having good utilization of library for their academic purpose and $57.14 \%$ having average utilization of library and $42.95 \%$ had poor utilization of library. Whereas $0.95 \%$ students are using internet as source of information, $44.76 \%$ are having average use of internet for the academic purposes and $54.28 \%$ is poor in utilization of internet for their studies. The above (Table 25) and (Figure 25) shows $40 \%$ students are very satisfied with utilization of college library, $56.19 \%$ is satisfied and $3.80 \%$ is less satisfied with the utilization of college library. Whereas $26.66 \%$ students are very satisfied with the utilization of collage internet, $60 \%$ is satisfied and $13.33 \%$ is less satisfied with the utilization of college internet.

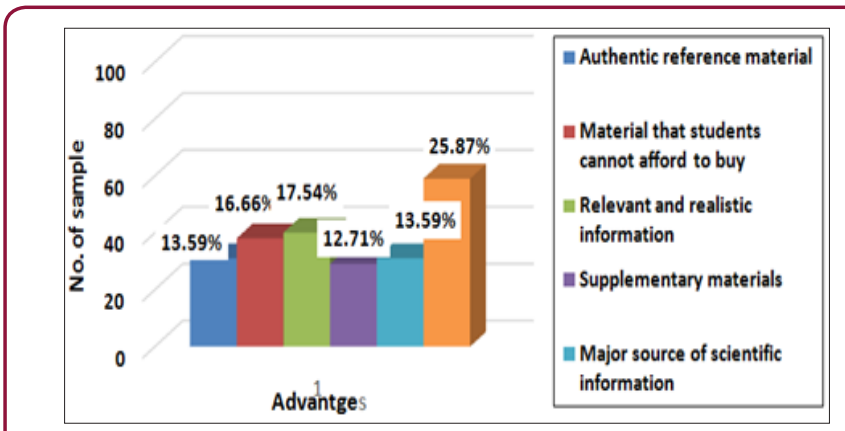

Figure 22: Advantages of reading materials available in internet.

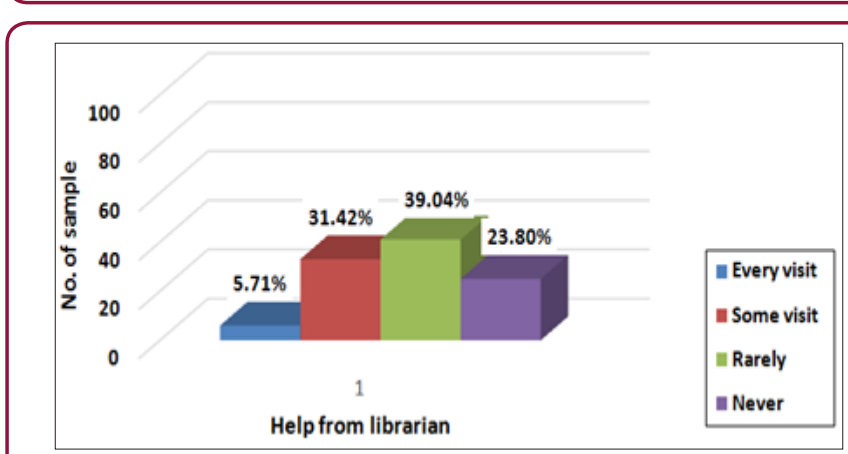

Figure 23: Asking help from librarian.

Table 22: Analysis of data related to advantages of reading material available in internet.

\begin{tabular}{|c|c|c|}
\hline Advantages & Score & Percentage \\
\hline Authentic reference material & 31 & $13.59 \%$ \\
\hline Material that students cannot afford to buy & 38 & $16.66 \%$ \\
\hline Relevant and realistic information & 40 & $17.54 \%$ \\
\hline
\end{tabular}




\begin{tabular}{|c|c|c|}
\hline Supplementary materials & 29 & $12.71 \%$ \\
\hline Major source of scientific information & 31 & $13.59 \%$ \\
\hline Resource are current \& update & 59 & $25.87 \%$ \\
\hline
\end{tabular}

Table 23: Analysis of data related to asking help from librarian.

\begin{tabular}{|c|c|c|}
\hline Asking help from Librarian & Score & Percentage \\
\hline Every visit & 6 & $5.71 \%$ \\
\hline Some visit & 33 & $31.42 \%$ \\
\hline Rarely & 41 & $39.04 \%$ \\
\hline Never & 25 & $23.80 \%$ \\
\hline
\end{tabular}

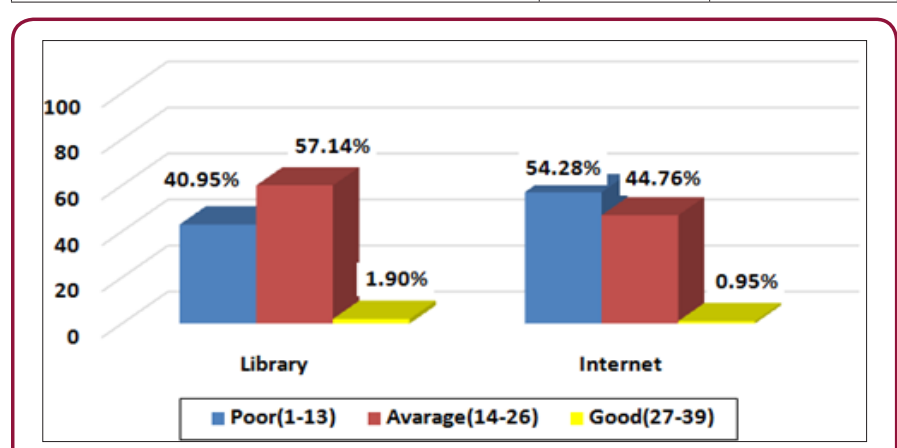

Figure 24: Comparison of library and internet.

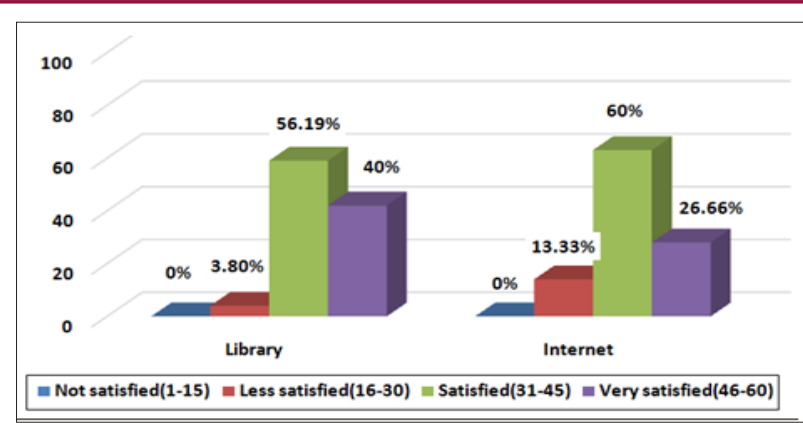

Figure 25: Comparison of satisfaction on utilization of college library and internet.

Table 24: Analysis of data related to comparison on utilization of library and internet.

\begin{tabular}{|c|c|c|c|c|}
\hline Score & Library & Internet & $\begin{array}{c}\text { Percentage } \\
\text { Library }\end{array}$ & $\begin{array}{c}\text { Percentage } \\
\text { Internet }\end{array}$ \\
\hline Poor(1-13) & 43 & 57 & $40.95 \%$ & $54.28 \%$ \\
\hline Average(14-26) & 60 & 47 & $57.14 \%$ & $44.76 \%$ \\
\hline Good(27-39) & 2 & 1 & $1.90 \%$ & $0.95 \%$ \\
\hline
\end{tabular}

Table 25: Analysis of data related to comparison of satisfaction on utilization of college library and internet.

\begin{tabular}{|c|c|c|c|c|}
\hline Scores & Library & Internet & $\begin{array}{c}\text { Percentage } \\
\text { Library }\end{array}$ & $\begin{array}{c}\text { Percentage } \\
\text { Internet }\end{array}$ \\
\hline Not satisfied(1-15) & 0 & 0 & 0 & 0 \\
\hline $\begin{array}{c}\text { Less } \\
\text { satisfied(16-30) }\end{array}$ & 4 & 14 & $3.80 \%$ & $13.33 \%$ \\
\hline Satisfied(31-45) & 59 & 63 & $56.19 \%$ & $60 \%$ \\
\hline $\begin{array}{c}\text { Very } \\
\text { satisfied(46-60) }\end{array}$ & 42 & 28 & $40 \%$ & $26.66 \%$ \\
\hline
\end{tabular}

\section{Discussion}

Findings of this study concludes that the utilization of the library and internet as a main source of scientific information by the nursing students. The result shows that maximum students are using library as source of scientific information for their academic purpose as compared to the internet. When compared with previous studies conducted in different professions utilization of library is maximum among nursing students. It is essential to note that majority of the respondents were informed that the library is helpful for the academic purpose over internet. Text books are the most preferred source for their studies than the other resource materials available in library. Average number of the students is visiting library every day. $40 \%$ students are very satisfied with utilization of college library, $56.19 \%$ is satisfied and $3.80 \%$ is less satisfied with the utilization of college library. Whereas $26.66 \%$ students are very satisfied with the utilization of collage internet, $60 \%$ is satisfied and $13.33 \%$ is less satisfied with the utilization of college internet. Following study also supports the present study:

\section{Mohamad Noorman Masrek (2014)}

Conducted a study on library usage of medical students: a comparative study of 1 st yr and 3rd yr students in university of Putra Malaysia. Adopting a survey research methodology involving 205 students, the findings suggest that, the they mostly used library. They concluded that third year students are most effectively use library as a source of information than first year students [3].

Chinmay Shah (27 Dec -2010): Conducted a study on library usage at an Indian medical college in Bhavanagar, Gujarat. The population was Gov. Medical students in Gujarat. the sample was 200 visitors of library.150 respondents were returns the forms, in that 130 from medical students and 20 from teachers. Findings shows that $42 \%$ of the respondents visited the library on daily basis, $15 \%$ went every other day, $26 \%$ once a week, $3 \%$ fortnightly, and $0.2 \%$ monthly, $11 \%$ used occasionally, $39 \%$ were spending $2-4$ hours in each visit [4].

Promise ifeoma ilo, goodluck I fijch (2010): Had conducted a study on impact of internet on final year students' research in covenant university ota, Nigeria. The study population comprised 1,467 final year students of 2010 session of covenant university. 150 final year students were randomly selected. findings says that $100 \%$ of students use internet and from that $94 \%$ said the internet had impact on their project work while $6 \%$ said the internet did not had any impact on their work, 52\% respondents said that the online journals made highest impact and $24 \%$ respondent said that the Online books had made more impact on study. 405 of students told that they are using Google as a search engine and 28\%using yahoo [5]. The previous studies show that majority of other professional courses access internet for their academic purpose over library. As we are living in digitalized world researchers found that still in nursing profession students are more depend on library due to increase written assignment, insufficient time for accessing internet etc. In this study; students mentioned that they are facing problem related to Sever down, Lack of security (virus), 
not providing authentic reference, lack of knowledge to access internet in correct manner while accessing internet. Nursing is a field where the updating of the knowledge is necessary to upgrade the nursing standard. Student should not only focus on the library to gain the knowledge but also they need to access the internet for their education and in betterment in clinical practice.

\section{Implication of the Study}

The finding of study has implication for nursing practice, nursing education, nursing administration and nursing research.

Nursing Practice: Study findings support need for nurse manager and other experienced nurses, to advocate for the accessibility of library resources, staff and services for practicing nurses. There should be expansion of health library collection, providing internet and internet access to nurses at bedside and investing in continuing education for nurses that will maximize the appropriate use of evidenced based information from research literature and will be practicing. Health care delivery largely deepens on information for effective decision making. As we enter the era of electronic health records nursing as become an indispensable element in the practice of nursing. All nurses have to utilize information skills in practice.

Nursing Education: Use by faculty during teaching activities may encourage students to make great and appropriate use of library and electronic information resources. Library is primary resources for evidence based practice. valuable in patient care quality care advice to patient avoiding adverse events, saving time.

Nursing Administration: In the event of ever changing knowledge explosion, technological and ever growing challenges of administration has a responsibility to provide the nurse with substantial continuing educational opportunity. This will enable the nurses in updating knowledge, acquiring special skill and demonstrating high quality care by deputing them for in service education program, special course, work shop and conference can be arranged and attended by the nursing staff. The finding of the study could be used by nursing administrators to take step in updating nursing standards and clinical practices.

Nursing Research: Nursing research is an essential aspect of nursing as it uplifts the profession and develops new nursing norms and body of knowledge. Another research has been added to nursing literature very few studies have been done on a similar basis. The research design, finding and the tool can be used as avenues for further research. There are no nursing studies in this area; more research need to undertaken is a need for extensive and intensive nursing research in this area. Finding of this study will provide baseline data about utilization of library and internet as a source of scientific information. All this information can be used for further research.

a) Limitation:The scope of the study was limited to nursing students residing in a selected nursing college.

b) The study was limited to those who utilized college library and internet.

c) The study limited to 105 samples.

d) The study limited to time.

\section{Recommendation: Following study can be undertaken in relation to present study:}

a) A study can be replicate on large sample there by finding can be generalized

b) A comparitive study can done between nursing and other medical profesion

c) A comparitive study can done between nursing students under the MUHS and deemed universities

d) A comparitive study can done between nursing students in urban nursing colleges and rural nursing colleges

e) A study can be conducted to asses the attitude of PG students in utilization of library and internet

f) A similar kind of study can be undertaken in different setting and on different target population.

\section{References}

1. Library of Alexandria.

2. History of the Internet.

3. Mohammad Noorman Masrek, Mohd Dasuki Sahak (2014) Library Usage of Medical Students: A Comparative Analysis of First Year and Third Year Students in Universiti Putra Malaysia. Procedia - Social and Behavioral Sciences 129: 127-132.

4. Chinmay Shah (2010) Case study: library usage at an Indian medical college. Health Information and Libraries Journal 28(1): 77-81.

5. Promise ifeomailo, goodluck I fijch (2010) Impact of the Internet on Final Year Students' Research: A Case Study of Covenant University, Ota, Nigeria. Library Philosophy and Practice (e-journal) p. 403.

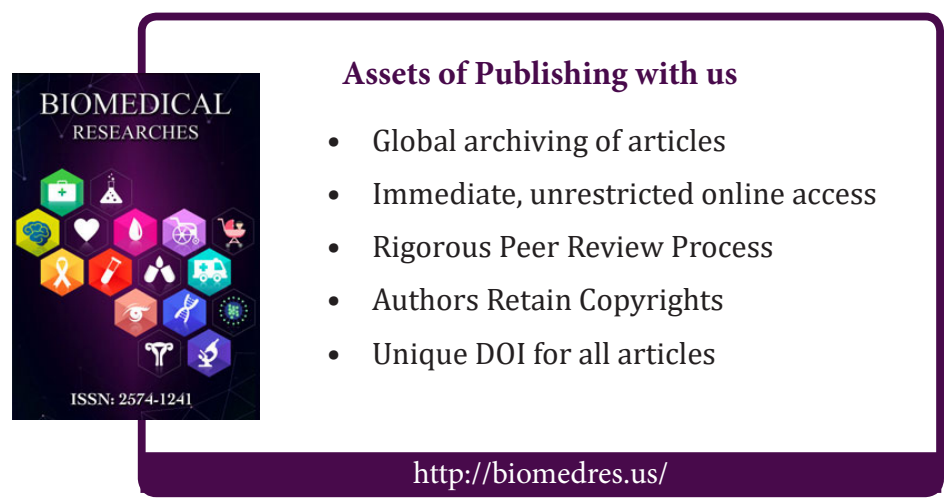

